\title{
CXCR4 Gene Mutation
}

National Cancer Institute

\section{Source}

National Cancer Institute. CXCR4 Gene Mutation. NCI Thesaurus. Code C150493.

A change in the nucleotide sequence of the CXCR4 gene. 